\title{
Serum proteins and enzymes levels in rats following co-administration of ethanolic leaf extracts of Ageratum conyzoides and Nigerian Bonnylight Crude Oil
}

\author{
Ita, S. O.* and Udotung, Y. C. \\ Departments of Physiology, University of Uyo, Uyo, Nigeria. \\ *Corresponding author. Email: uloro2003@yahoo.com. Tel: +2348033890830.
}

Copyright (@ 2017 Ita and Udotung. This article remains permanently open access under the terms of the Creative Commons Attribution License 4.0, which permits unrestricted use, distribution, and reproduction in any medium, provided the original work is properly cited.

Received 22nd June, 2017; Accepted 11th July, 2017

\begin{abstract}
The role of administration of leaf extract of Ageratum conyzoides following the administration of Nigerian Bonnylight crude oil (NBLCO) on serum proteins and enzymes was investigated. Twenty female Wistar rats (120 to 150 $\mathrm{g}$ body weight) were divided into four groups of five rats each. The rats in group I served as the control group and were oral gavaged $3 \mathrm{ml} / \mathrm{kg}$ of normal saline; group II gavaged $748.33 \mathrm{mg} / \mathrm{kg}$ body weight of the extract of $A$. conyzoides, which was $20 \%$ of the LD50 $(3741.66 \mathrm{mg} / \mathrm{kg})$. Group III was gavaged $3 \mathrm{ml} / \mathrm{kg}$ body weight of NBLCO. This dose was calculated as $20 \%$ of the lethal dose of $14.14 \mathrm{ml} / \mathrm{kg}$. Group IV animals were gavaged $748.33 \mathrm{mg} / \mathrm{kg}$ body weight of the extract of $A$. conyzoides, and $3 \mathrm{ml} / \mathrm{kg}$ body weight of NBLCO. In all cases, doses were applied daily for 31 days according to animal's most recent body weight. The results showed that NBLCO significantly increase serum albumin, globulin, fibrinogen Alanine transaminase (ALT), aspartate aminotransferase (AST) and Alkaline phosphatase (ALP) compared with groups I and II $(\mathrm{P}<0.05)$. Co-administration of leaf extracts of $A$. conyzoides with NBLCO caused significant reduction in the aforementioned parameters when compared with crude oil group $(p<0.05)$. It is concluded that co-administration of the ethanolic leaf extracts of Ageratum conyzoides with the NBLCO can be hepatoprotective to the extent of ameliorating its hazardous effects on the liver cells.
\end{abstract}

Keywords: Ageratum conyzoides, rats, Bonnylight crude oil, albumin, globulin, serum enzymes.

\section{INTRODUCTION}

The liver is pivotal to the normal development, synthetic, metabolic and physiological balance such that alteration in hepatic function potent great consequences to the body. Determination of serum protein including albumin is an index in assessing synthetic function of the liver as plasma proteins are synthesized in the liver. Furthermore, the assessment of Alanine transaminase (ALT) and aspartate aminotransferase (AST) can be used to diagnose a wide spread organic damages. ALT occur in the cytosol of the liver, while AST has cytosolic and mitochondrial forms and is present in various tissues including the liver, heart, skeletal muscle, kidneys, brain, pancreas and indeed blood cells (Batzakis and Briere, 1979). Hepatic damage is usually associated with elevated serum ALT, AST and bilirubin concentration (Kew, 2000; Green and Flamm, 2002; Collier and
Bassendine, 2002). Many environmental insults through accidental discharge, pollution of various kinds, industrial and work place exposure including NBLCO can on exposure inflict dangerous injury on organs and tissues of the body. And such hepatocellular injury can ultimately cause hepatocellular damage to compromise the synthetic function of the liver as well as liberating ALT and AST to flood the extracellular compartment as indicators of such damages.

The modern world is technologically driven and quest for industrial expansion remain unabated and as such the emission of these insults with tendency to cause tissue and cellular injury will remain unabated for a long time. A search for cheaper and readily available substance(s) with efficient potentials to ameliorate the harmful effects of these insults is novel. Many herbaceous plants have 
been reported to possess such property; among this group of herbaceous plant with therapeutic potentials is Ageratum conyzoides. Ageratum conyzoides is an herbaceous plant used in several countries of the world for its medicinal and therapeutic purposes. The use of this herb as a bacteriocide, antidysentric and antibiotic has been reported for communities in Asia, Africa, India and South America (Almagboul, 1985; Ekundayo et al., 1988; Borthakur and Barauh, 1987).

In some local communities in Nigeria, the leaves of Ageratum conyzoides are used in the management of fever, pneumonia and rheumatism. Various parts of this plant contain many secondary metabolites (Kong et al., 2004) which are responsible for its reported medicinal and therapeutic effects. The ethanolic extracts of the roots and aerial parts of $A$. conyzoides have been reported to exhibit gastroprotective activity by blocking $\mathrm{Ca}^{2+}$ channels and antiserotogenic properties (Achola et al., 1994). Ita et al. (2007) have also reported the advantageous effect of the ethanolic leaf extract on haematological indices of rats as a blood booster. The ethanolic leaf extracts of $A$. conyzoides is recently reported to improve erythrocyte membrane resistant to NBLCO induced haemolysis (Ita and Nya, 2017). The medicinal and therapeutic benefits of $A$. conyzoides have been attributed to its phenolic content. The hydroxytyrosol content of this plant can prevent cardiovascular disease by reducing the expression of adhesion molecules on endothelial cells and preventing the oxidation of low density lipoprotein (Rafehi et al., 2012).

One of the organs usually affected by ingestion of xenobiotic insults because of its central role in synthetic, metabolic and detoxification activities is the liver. Generally, hepatic injury is often associated with alterations in the serum and liver levels of some enzymes notably ALT, AST and ALP (Whitby et al., 1984) and studies with medicinal plant extracts have shown the varying effects of phytochemicals on serum and liver enzyme levels. While some phytochemicals are hepatotoxic, others are hepato-protective. Many researchers in these fields have reported changes in ALT, AST, ALP, GGT (gamma glutamyl transferase) activeties in animals treated with plant extracts (Nada et al., 1997; Udosen and Ojong, 1998; Bumah et al., 2005; Akpanabiatu et al., 2005). Thus, this study is design to evaluate the ameliorating potentials of Ageratum conyzoides against NBLCO hazardous effects on the liver.

\section{MATERIALS AND METHODS}

The crude petroleum used in this study was obtained from the Exxon Mobil laboratory, Ibeno, Nigeria.

\section{Collection of plant material}

The whole plant was obtained from the Botanical farm of the Department of Pharmacognosy and Natural Medicine, University of Uyo, Uyo, Nigeria. Specimen of the leaves was authenticated by Dr. (Mrs.) Uduak Aniema Essiett of the Department of Botany and Ecological Studies, University of Uyo, Uyo. A voucher specimen (UUH 3517) was deposited at the Herbarium.

\section{Preparation of leave extract}

The leaves of $A$. conyzoides were rinsed with distilled water and dried under shade. The dried leaves were ground into powder with an electric blender. Four hundred grammes $(400 \mathrm{~g})$ of the blended leaves sample was macerated in $700 \mathrm{ml} 70 \%$ ethanol, agitated for 10 minutes with an electric blender and left overnight in a refrigerator at $4^{\circ} \mathrm{C}$. The mixture was filtered with a cheese cloth and the filtrate obtained concentrated under reduced pressure using a rotary evaporator $\left(\right.$ at $37^{\circ} \mathrm{C}$ ) to about $10 \%$ of its original volume. The concentrate was then allowed in a water bath at $37^{\circ} \mathrm{C}$ for complete evaporation to dryness yielding $40.64 \mathrm{~g}(10.15 \%)$ of the extract.

\section{Acute toxicity test}

Acute toxicity study (LD50) was estimated using Lorke's method (Lorke, 1993). A total of 25 mice weighing between 15 to $22 \mathrm{~g}$ were divided into five groups with five mice per group. Mice in the five groups were administered $3000 \mathrm{mg} / \mathrm{kg}, 3500 \mathrm{mg} / \mathrm{kg}, 4000 \mathrm{mg} / \mathrm{kg}$, $4500 \mathrm{mg} / \mathrm{kg}$ and $5000 \mathrm{ml} / \mathrm{kg}$ of body weight respectively (intraperitoneally). All experimental animals were observed for physical signs of toxicity such as gasping, palpitation, writhing, decreased respiratory rate, body limb and death after 24 hours.

The median lethal dose of Agerantum conyzoides was calculated as geometrical means of the maximum (most tolerable) dose producing $0 \%$ mortality (a) and the minimum (least tolerable) dose producing $100 \%$ mortality (b) using the formula:

$$
\begin{aligned}
\mathrm{LD}_{50} & =\sqrt{ } \mathrm{ab} \\
\mathrm{LD}_{50} & =\sqrt{ } 3500 \times 4000 \\
& =3741.66 \mathrm{mg} / \mathrm{kg}
\end{aligned}
$$

The acute toxicity test for the NBLCO also involved 25 mice weighing between 15 to $22 \mathrm{~g}$ were divided into five groups with five mice per group. Mice in the five groups were administered intraperitoneally $10 \mathrm{ml} / \mathrm{kg}, 15 \mathrm{ml} / \mathrm{kg}$, $20 \mathrm{ml} / \mathrm{kg}, 25 \mathrm{ml} / \mathrm{kg}$ and $30 \mathrm{ml} / \mathrm{kg}$ of body weight respectively.

$$
\begin{aligned}
\operatorname{LD}_{50} & =\sqrt{ } 10 \times 20 \\
& =14.14 \mathrm{ml} / \mathrm{kg}
\end{aligned}
$$




\section{Experimental animals}

Female Albino Wistar rats weighing between 150 to $180 \mathrm{~g}$ were obtained from the Animal House of the Faculty of Basic Medical Sciences University of Uyo, Uyo, Nigeria and were kept in a well-ventilated section of the Animal House. They were allowed access to feed (Chow: vital feeds, Grand Cereals Ltd, Jos) and water ad libitum. The animals were kept in separate experimental room and allowed to acclimatize for a period of one week before commencement of studies.

\section{Experimental design and treatment of animals}

A total of twenty (20) adult female Albino Wistar rats were randomly divided into four groups (group I, II, III and IV) of five (5) rats each. Group I served as the control and was oral gavaged $3 \mathrm{ml} / \mathrm{kg}$ body weight of normal saline. Group II was oral gavaged $748.33 \mathrm{mg} / \mathrm{kg}$ body weight of ethanolic leaf extracts of Ageratum conyzoides, this dose was calculated as $20 \%$ of the lethal dose $\left(L_{50}\right)$ of $3741.66 \mathrm{mg} / \mathrm{kg}$. Group III was oral gavaged $3 \mathrm{ml} / \mathrm{kg}$ body weight of NBLCO. This dose was calculated as $20 \%$ of the lethal dose $\left(L D_{50}\right)$ of $14.14 \mathrm{ml} / \mathrm{kg}$, while group IV in addition to $3 \mathrm{ml} / \mathrm{kg}$ body weight of NBLCO, were supplemented with $748.33 \mathrm{mg} / \mathrm{kg}$ body weight of ethanolic leaf extracts of Ageratum conyzoides. In all cases, the doses were based on the rat's most recently recorded body weight. The calculated volume in milliliter (ml) was applied daily for thirty one (31) days. The experimental procedures involving the animals and their care were conducted in conformity with the approved guidelines by the Research and Ethical Committee of the Faculty of Basic Medical Sciences, University of Uyo, Uyo. Nigeria.

\section{Collection of blood sample for analysis}

After the thirty one (31) days of administration, the rats were anaesthetized with chloroform soaked in swap of cotton wool in a killing chamber. Blood was collected by cardiac puncture with a $5 \mathrm{ml}$ sterile syringe and needle. The total volume of blood collected was $4 \mathrm{ml}$, which was transferred into plain sample bottles. This was allowed to stand for 2 hours to clot after which the serum was separated by centrifugation (RM-12 micro centrifuge, REMI, England) at $4000 \mathrm{rpm}$ for 10 minutes. The serum obtained was stored at $-4^{\circ} \mathrm{C}$ until required for analysis. Storage did not last more than 30 hours as all biochemical analysis were concluded 28 hours after serum collection.

\section{Determination of Albumin}

Albumin was estimated with albumin reagent from Dialab, France as described by Tietz (1994).

\section{Determination of Globulin}

Serum globulin concentration $=$ Total protein - serum albumin as described by Tietz (1995).

\section{Evaluation of serum activities of AST, ALT and ALP}

Serum activities of ALT, AST and ALP were estimated using laboratory kits obtained from Randox laboratory Ltd., United Kingdom and absorbance were read using a uv-vis spectrophotometer (DREL $300 \mathrm{HACH}$ ).

\section{Statistical analysis}

Data were expressed as the mean \pm standard error of the mean. Statistical analysis was carried out using window SPSS package (SPSS 22.00 version). Data were analyzed using one way analysis of variance (ANOVA) and results obtained were further subjected to test for least significant difference (LSD). Values of $\mathrm{P}<0.05$ were considered significant.

\section{RESULTS}

The results of some plasma proteins profile obtained after 31 days administration are shown in Table 1. The administration of Nigerian Bonnylight crude oil to group III animals significantly increased albumin, globulin and fibrinogen levels compare to groups I (normal saline) and II $(A$. conyzoides) $(p<0.05)$. The co-administration of the leaf extracts of Ageratum conyzoides to group IV animals significantly reduce albumin and fibrinogen levels with respect to groups I, II and III $(p<0.05)$ but did not significantly altered globulin level.

Similarly, the results of AST, ALT and ALP activities obtained after 31 days administration are shown in Table 2. The administration of Nigerian Bonnylight crude oil to group III animals significantly increased the enzymes activity compare to groups I (normal saline) and II ( $A$. conyzoides) $(p<0.05)$. The co-administration of the leaf extracts of Ageratum conyzoides to group IV animals significantly reduce the activity of these enzymes with respect to group III administered only NBLCO $(p<0.05)$.

\section{DISCUSSION}

In many regions of the world medicinal plants contribute immensely to the healthcare of the population. Many rural dwellers depend in many ways on a variety of plant materials for their wellbeing. These plants do not only supply essential nutrients but contain secondary metabolites which have proven to be efficacious against many diseases. In our local communities Ageratumconyzoides commonly referred to as "goat weed" is used for the 
Table 1. Comparison of albumin, globulin and fibrinogen in rats following exposure to NBLCO and ethanolic leaf extracts of Ageratumconyzoides for 31 days.

\begin{tabular}{lccc}
\hline Groups & Albumin $(\mathbf{g} / \mathbf{d L})$ & Globulin $(\mathbf{g} / \mathbf{d L})$ & Fibrinogen $(\mathbf{m g} / \mathbf{d L})$ \\
\hline I (Normal saline) & $3.59 \pm 0.13$ & $2.70 \pm 0.38$ & $13.90 \pm 0.63$ \\
II (A. conyzoides) & $4.17 \pm 0.11^{\mathrm{a}}$ & $2.55 \pm 0.12$ & $6.22 \pm 0.75^{\mathrm{a}}$ \\
III (NBLCO) & $6.16 \pm 0.22^{\mathrm{a}, \mathrm{b}}$ & $3.42 \pm 0.01^{\mathrm{a}, \mathrm{b}}$ & $41.50 \pm 2.59^{\mathrm{a}, \mathrm{b}}$ \\
IV (NBLCO + A. conyzoides) & $4.97 \pm 0.90^{\mathrm{a}, \mathrm{b}, \mathrm{c}}$ & $2.85 \pm 0.13$ & $30.17 \pm 0.60^{\mathrm{a}, \mathrm{b}, \mathrm{c}}$ \\
\hline
\end{tabular}

a, significantly different from group I $(p<0.05)$, b, significantly different from group II $(p<0.05)$ and $\mathbf{c}$, significantly different from group III $(p<0.05)$.

Table 2. Comparison of AST, ALT and ALP in rats following exposure to NBLCO and ethanolic leaf extracts of Ageratumconyzoides for 31 days.

\begin{tabular}{lccc}
\hline Groups & AST $(\boldsymbol{\mu} / \mathbf{L})$ & ALT $((\boldsymbol{\mu} / \mathbf{L}))$ & ALP $((\boldsymbol{\mu} / \mathbf{L}))$ \\
\hline I (Normal saline) & $71.88 \pm 1.40$ & $25.00 \pm 2.03$ & $39.00 \pm 3.16$ \\
II (A. conyzoides) & $83.83 \pm 1.40$ & $40.17 \pm 1.54^{\mathrm{a}}$ & $68.83 \pm 4.71^{\mathrm{a}}$ \\
III (NBLCO) & $236.83 \pm 6.93^{\mathrm{a}, \mathrm{b}}$ & $66.67 \pm 4.30^{\mathrm{a}, \mathrm{b}}$ & $169.35 \pm 4.11^{\mathrm{a}, \mathrm{b}}$ \\
IV (NBLCO + A. conyzoides) & $187.00 \pm 3.42^{\mathrm{a}, \mathrm{b}, \mathrm{c}}$ & $47.83 \pm 1.42^{\mathrm{a}, \mathrm{b}, \mathrm{c}}$ & $140.67 \pm 5.31^{\mathrm{a}, \mathrm{b}, \mathrm{c}}$ \\
\hline
\end{tabular}

a, significantly different from group I $(p<0.05)$, $\mathbf{b}$, significantly different from group II $(p<0.05)$ and $\mathbf{c}$, significantly different from group III $(p<0.05)$.

treatment of fever, rheumatism, pneumonia, wounds, dysentery, etc. This study examined the ameliorating potentials of ethanol leaf extracts of Ageratum conyzoides on serum levels of albumin, globulin, fibrinogen, AST, ALT and ALP activities. These results provide evidence that NBLCO has a damaging effect on the hepatocellular cells. Such injurious effects underscore the significantly higher globulin and albumin levels as well as the high activities of AST, ALT and ALP observed in this present study.

It is important to note that AST in particular is a mitochondrial enzyme; the flooding of plasma by enzyme that ordinarily is restricted to hepatocellular mitochondrial compartment is suggestive of toxic injury caused by the ingested NBLCO. This finding is corroborated by similar injurious effect on erythrocyte membrane where oral ingestion of NBLCO damages erythrocyte membrane to cause haemolysis resulting in anaemia (Ita et al., 2013). It is also important to note that NBLCO is toxic to the extent that a minute concentration in the environment can cause a lot of physiological changes in the body of an exposed organism (Ezenwaji et al., 2012).

\section{Conclusion}

The ameliorating efficacy of Ageratum conyzoides observed in this present study is evidenced by the significant reversal of the aforementioned parameters. Previous works on Ageratum conyzoids reported its efficacy as antibiotic, anti-inflammatory agent (Durodola, 1977; Ekundayo et al., 1988). It is concluded that co- administration of the ethanolic leaf extracts of Ageratum conyzoides with the NBLCO can be hepato protective to the extent of ameliorating its hazardous effects on the liver cells.

\section{CONFLICT OF INTEREST}

The authors declare that they have no conflict of interest.

\section{REFERENCES}

Achola, K. J., Munenge, R. W., \& Mwaura, A. M. (1994) Pharmacological properties of root and aerial extracts of Ageratum Conyzoides on isolated ileum and heart. Fitoterapia, 66, 322-325.

Akpanabiatu, M. I., Umoh, I. B., Eyong, E. U., \& Udoh, F. V. (2005). Influence of Nauclea on rats fed on Coconut oil and non-coconut oil meals. Pharmaceut. Biol., 43(2), 53-157.

Almagboul, A. Z., Farroq, A. A., \& Tyagi, B. R. (1985). Antimicrobial activity of certain Sudanese plants used in folkloric medicine; screening for antibacterial activity, part II. Fitoterapia, 56, 103-109.

Batzakis, K. G., \& Briere, R. O. (1979). Interpretative Enzymology. Thomas Nelson, liiinois, Springfield, Pp. 225242.

Borthakur, N., \& Barauh, A. K. (1987). Search for precocenes in Ageratum Conyzoides L. of North-East India. J. Indian Chem. Soc.. 64:540-581.

Bumah, V. V., Essien, E. U., Agbedahunsi, J. M., \& Eka, O. U. (2005). Effect of Khaya grandifoliala (Melianceae) on some biochemical parameters in rats. J. Ethnopharmacol. 102(3), 446-449.

Collier, J., \& Bassendine, M. (2002). How to respond to 
abnormal liver function tests. Clin Med., 26, 606-614.

Durodola, J. J. (1977) Antibacterial property of crude extracts from herbal wound healing remedy - Ageratum Conyzoides Planta Med., 32, 385-390.

Ekundayo, O., Sharma, O. S., Rao, E. V. (1988) Essential Oil of Ageratum Conyzoides. Planta Med. 154, 55-57.

Ezenwaji, N. E., Yenagoa, B., \& Nwaigwe, C. (2012). Changes in liver and plasma enzymes of Charias gariepinus exposed to sub-lethal concentration of diesel. African Journal of Biotechnology, 12(4), 414-418.

Green, R. M., \& Flamm, S. (2002).AGA technical review of the evaluation of liver chemistry tests. Gastroenterology, 123, 1367-1384.

Ita, S. O., Etim, O. E., Ben, E. E., \& Ekpo, O. F. (2007) Haematopoietic properties of ethanolic leaf extract of Ageratum conyzoides in albino rats. Niger. J. Physiol. Sci., 22(1-2), 83-87.

Ita, S. O., Aluko, E. O., Atang, D. E., Antai, A. B., \& Osim, E. E., (2013). Vitamin C or E Supplementation Ameliorates Nigerian Bonny Light Crude Oil-induced Erythrocyte Haemolysis in Male Wistar Rats. Biochemistry and Molecular Biology, 1(3), 44-51.

Ita, S. O., \& Nya, M. E. (2017). Co-Administration of Crude Ethanolic Leaf Extract of Ageratum conyzoides ameliorates Nigerian Bonnylight Crude Oil-Induced Erythrocyte Haemolysis in Female Wistar Rats. IOSR Journal of Pharmacy and Biological Sciences (IOSR-JPBS), 12(3), 7377.
Kong, C. H., Hu, F., Hu, X. H., Liang, W. J., \& Zhang, C. X. (2004). Allelopathic plants. XV. Ageratum Conyzoides L. Allelopathy Journal, 14, 1-12.

Kew, M. C. (2000). Serum aminotransferase concentration as evidence of hepatocellular damage. Lancet, 355, 591-592.

Lorke, D. (1993). A New Approach to Practical Acute Toxicity Testing. Arch Toxicol., 54, 275-287.

Nada, S. A., Bashandy, S. A. E., \& Negam, A. A. (1997). Evaluation of the hypoglycaemic activity of traditional herbal preparation in male diabetic rats. Fitoterapia, 68 (3): 240-244.

Rafehi, H., Vervaris, K., \& Karagiannis, T. C. (2012). Mechanisms of action of phenolic compounds in Olive. J. Diet Suppl., 9((2), 96-109.

Tietz, N. W. (1994). Textbook of Clinical Chemistry. 2nd Ed. W.B. Saunders Company, Philadelphia. p. 703.

Tietz, N.W. (1995). Clinical guide to laboratory tests. 3rd Ed. W.B. Saunders Company, Philadelphia. p. 105.

Udosen, E. O., \& Ojong, A. S. (1998). Hepatotoxic activity of Sacoglottis gabonensis in rats. Pharmaceut. Biol., 36(5), 368371.

Whitby, L. G., Percy-Robb, I. W., \& Smith, A. F. (1984). Enzymes test in diagnosis. In: Lecture notes on Clinical Chemistry, 3rd ed. Blackwell Sci. Publication, London, Pp. 138-168. 